\title{
Shiite and Sunni Political Expediency Position in Jurisprudence: A Case Study of Political Thought of Imam Komeini and Abu Ishaq Shatby
}

\author{
Marzieh Samaei Sahneh Saraei ${ }^{1}$, Jalal Dorakhshah ${ }^{2} \&$ Rahim Khastu ${ }^{1}$ \\ ${ }^{1}$ Department of Political Sciences, College of Law and Political Sciences, Karaj Branch, Islamic Azad \\ University, Karaj, Iran \\ ${ }^{2}$ Department of Political Sciences, Imam Sadegh University, Thran, Iran \\ Correspondence: Jalal Dorakhshah, Department of Political Sciences, Imam Sadegh University, Thran, Iran. \\ E-mail: Jalal Dorakhshah@yahoo.com
}

$\begin{aligned} & \text { Received: July 12, } 2016 \quad \text { Accepted: August 18, } 2016 \quad \text { Online Published: September 29, } 2016 \\ & \text { doi:10.5539/jpl.v9n8p108 }\end{aligned} \quad$ URL: http://dx.doi.org/10.5539/jpl.v9n8p108

\begin{abstract}
"Interest" is one of the basic concepts of political jurisprudence that Shia and Sunni scholars have developed different opinions about it. In the sphere of Shiite political jurisprudence, especially after the Islamic Revolution of Iran, the concept was deemed appropriate status in the vote and the views of Imam Khomeini were manifested. In Sunni jurisprudence, numerous scholars have examined this issue that they can be named the most outstanding Abu Isac Shatby. In this article, the question is: what are the differences and similarities of Imam Khomeini's viewpoints of Abu Isac Shatby on the issue of the interest and the research method is descriptive and regarding the title is matching that is woth for exploration and investigation.
\end{abstract}

Keywords: interest, political jurisprudence, Imam Komeini, Shatby

\section{Introduction}

The concept of interest as the basis for legislation, among the issues that the world of Islam has been a controversial consideration and much debated and this indicates the importance of the interest in Islamic jurisprudence. But the interest in legal terms, has no comprehensive and approved definitions by all Islamic scholars, and it makes also difficult tp agree. The concept of interest in jurisprudence, was considered and studied in Sunni viewpoint during the centuries because of its connection to the sovereignty and domination of power. But this concept is not accepted in Shiite jurisprudence ever within the framework of the Sunni jurists. Subject interest in following the Shiite jurisprudence and the principles it has always been considered. Materialistic and individualistic attitude towards expediency is considered in such a way that worldly gains attention only slight angle and material means. In this approach the only people to profit more worldly sense. And it is the only rule that has identified a part of the enjoyment of this benefit with the aim of breaking the privacy of others. The difference between these two approaches is that the Islamic approach, in addition to the value of independent intellectual interests, in many cases the former are material considerations.

The famous hadith, "the actions are determined by the intentions" reflects this point. Interest in the political world as well as personal and social behavior, is of particular importance. In politics, as well as personal and social life of human beings, when politicians are faced with a conflict of interest, they rely on the interest which is more important. This is important in the development of greater Islamic state. Because the Islamic state warrants the fixed and variable provisions on one hand, and on the other hand, it is containing the absolute subject of supreme leader. Since that members of the supreme leader are appointed by the Immaculate, are obliged to observe the public interest and should consider the interests of society.

\section{Concept of Interest}

\subsection{Lexical Meaning}

Interest in commonsense terms, political and legal literature has multiple meanings and usage and very desirable and undesirable meanings can be understood. The main root of the word of interest is the peace and prosperity. Its synonym is good, profitable, and evil, etc. 
The controversial concept of interest is, both synonym and cognate with many other concepts. Among the meanings of the Arabic language can refer to meaning that Ghorbanzadeh quotes Ibn al-Jawahiri and Ibn Manzoor has noted that higher order "Alslah anti Alfsad and Almslhh, single Almsalh, Al-Islah contradictory Alfsad and Almslhh, Alslah."Peace is against the evil and the interest unifies the categories. (Ghorbanzadeh, 2002: 55)

\subsection{Idiomatic Meaning}

Idiomatic meaning of interest comparing its literal concept has less diversity and more scribes, usually conforfimed Ghazali definition of interest. "Our definition of the best interest is the protection of religion, life, intellect, generation, and property interests in each of these five principles"(Ghazali, $1302 \mathrm{AH}$ : 140). And one of the most important differences between true religions is secular interest in religion and by the divine essence of religions and Islam comprises two horizons of earthly and material; while non-interest approach is purely material nature (Eftekhari, 2005: 38-37). While interest in Islamic thinking in terms of time includes a period that at the time, the religion gets meaning, namely considers the world and the hereafter, however, it may be similar in appearance to Western definitions. God says in the Quran: "You are what God has given you, search hereafter and this way do not forget thy portion of the world" (Al-Qasas / 77). Given the fundamental differences in the reasons and religious orders, and Sunni and Shiite resources of jurisprudence existed between scholars to explain the concept of interest with respect to this research, genealogy forced to express interest from the Shia and Sunni perspectives.

\section{Types of Interest}

\subsection{Interest, Philosophy Legislation Commandments}

Interest in Islamic teachings has various meanings. According to one meaning - that make many dialogue and conflict Kalam knowledge - good and evil, philosophy, are counterfeit for religious orders and Shi'ites and Mu'tazilites based on the theory are cached in the obligatory and forbidden, the good and evil of which causes a necessity and dignity of forgery (Hoor Ameli, 1414: 310). In contrast, Ash'arites accepted this view and have denied the rational good and bad have not expedient due to corruption and forgery of religious orders.

\subsection{Interest, Reason for the Interpretation of Religious Orders}

Many Sunni scholars have considered interest as a reason for the interpretation of religious orders. They believe that if the text, there is no consensus and analogy and it is not the abolition or revulsion by the legislator of interest, the interest can be inferred to cite Search Sutra (Shatby, 1421 AH: 39). Sunni jurists disagree about the validity of interest materials and there are the efforts to expand the coverage of their right to seek consensus and reconciliation among the four Sunni groups that they were void and this disagreement still exists. In summary, it can be said that in some quotes of Malekids and Shafi'i and Hanbali group, it is considered as an argument. (Shatby, 1416, vol. 1: 351)

Standing interest in political jurisprudence of Khomeini and Abu Isac al-Shatby

\section{Biographies of Imam Komeini}

Ruhollah Musawi Khomeini was born on the tenth day of Jamadi al-Thani 1320 AH corresponding to 30 September 1281 Hijri in the city Khomeini, Iran's central province (website). His father named Mostafa Mousavi and the name of his mother was Hajar. His father was died in his childhood. Seyed Mostafa was killed by the Khans backed by government agent at the time. He was trained during childhood and adolescence under the protection of his mother and aunt (Sahebeh). Major works holiness in seven subjects of philosophy and mysticism, jurisprudence, principles, ethics, Tafsir Majid, poetry and literature, and government and politics is as follows:

Floodlight of guidance to the succession and the state (Arabic countenance of Allah (Persian), The mystery of prayer, commenting on the judgment explained cloves (Arabic), Commenting on mankind Floodlight (Arabic), Commenting on the commentary on the hadeeth of the head of Galot (Arabic), commentary on the hadeeth of the head of Galot (Arabic), interpretation of Sura al-Fatiha (Persian), Footnote on Scriptures (Arabic), customs of prayer (Persian), anti-esteem, Great Jihad (Persian), Hadith description of the host, wisdom and ignorance (Persian), Arba'een - Arba'een days description (Persian), books on jurisprudence argument, Book of Purity, Forbidden gains, Book of sales, Book of bugs, Message in dissimulation, Message in the base of property, Message in the appointment of dawn in moonlit nights, Message that does not harm, Message in a tie and priorities, Message of ijtihad and tradition, Message in demand and will, Commenting on the adequacy of assets (Persian) and so on (Moradinia, 2006: 48-47 and the Institute for preservation of works of Imam Khomeini). Spirit of struggle and jihad for God was the prominent feature of his adolescence. He, after the death of 
Ayatollah Boroujerdi was selected as Zaim of Islamic seminary, but gradually assumed as leadership of the religious community but with the view side of cruelty, he resisted against the false and treacherous politics of Pahlavi regime. The first signs of his opposition to the government bill occured on the subject of the 1962 provincial associations. 1963 New Year was begun by proscribing celebration, he rosed against the regime and Feyziyeh School became red with the blood of the oppressed. Imam Khomeini in the evening of Ashura on 13 June $1963 \mathrm{AD}$ in the school of Feyziyeh, who started his uprising by his historic speech delivered on the 15th of November. Fifteen November 1964 Imam was arrested and imprisoned at dawn on June 1963. In the wake of the continuing struggles of the regime, the morning of 13 November 1964 he was deported to Turkey and from there to Iraq.

Imam Khomeini was able to gain some enlightenment to change the atmosphere of Najaf. Now, in 1969, in addition to numerous militants inside the country, so many in Iraq, Lebanon and other Islamic countries, which knew Imam Khomeini's movement as his model. Imam Khomeini's Revolutionary Council was formed on January 1978. Finally, Imam Khomeini in morning of 12 February 1978, after 14 years return from the exile to the country with unprecedented welcome people. On 22 February, the Iranian revolution triumphed. It was the world's first Shiite Islamic government that came along with people and their leadership. After the victory, Imam faced with problems. One of the most important barriers was in both the parliament and the Guardian Council. This leads to the Imam's decree on the formation of the Expediency Council, which in this case was the task of final verdict. The morning of sixteen June 1989, the largest event took place by the millions of grieving nation after two days of farewell to his body in Tehran. Imam Khomeini died after suffering at the age of eighty.

\subsection{Jurisprudence at Imam Khomeini's Views and Interests in Its Place}

Imam Khomeini is known from the perspective of jurisprudence as the jurist of Jawaheri style that religious Shiites committed it. He emphasized the issue of time and place under today's different conditions that were seeking to redefine their legal content (Khomeini, 1999: 98). According to him the jurisprudence is the sum of the efforts of scholars to answer questions and needs of the people. He examined the jurisprudence based on the theory of governing the society. As he says:

"Jurisprudence is the true and complete guideline for man and society from cradle to the grave." (Khomeini, 1999: 98).

This statement reveals the nature of the law according to him so that worldly affairs of society are concerned according to the principles set by the legislator. According to the law, the public interest is so mixed with the jurisprudence that a jurist cannot be unaware of the political and social issues because the law in his views is mixed with all human social life. Basic materials in his legal school raised as a matter of principle in ijtihad. Imam about the importance of religious consciousness with the needs of time and place of their society says: "It's important to recognize the right of government and society that according to it, the Islamic system can plan for the benefit of Muslims... Ijtihad is not enough in the common areas. But a person knowledgeable is in the field of traditional knowledge but fails to recognize the good of society and in general, social and political field lacks insight and decision-making power, the social and government priest cannot take the reins of society. "(Khomeini, 1999: 217)

\section{Expediency of Imam Khomeini}

Extraction of theological and legal foundations of Khomeini's theory of primary and secondary importance to the provisions of the Islamic state of today is the most challenging legal issues.

According to Imam Khomeini, interest means an interest that is open to the community and broad scope; so that includes the secular, worldly and culturally, economic, political interests and so on, and it means that it is different so much to the interest of the Sunnis to expand the coverage. The interest in the sense is of the most important provisions of the government and community leaders should be aware of their decisions (Hussaini, 2001: 2-6). As the preceding discussion, the association of interest to the Supreme Leader and we explain the Islamic Republic, Imam Khomeini's doctrine of velayat-e faqih is referred to the role of interest wherever and whenever appropriate, the Muslim jurists materials, in some of its authority, sentences that everyone should follow them (Khomeini, 1990: 35). Therefore, the interests of the provinces and theocracy becomes much more important, because maintaining a constant religion knows himself responsible as the Islamic state warrants the constant and variable containing the provisions for resolving the crisis at different times. Supreme Leader as the reference in occultation period will do this work through the mechanism of the expediency outer and inner mechanism according to their scientific abilities (Fathy, 1999: 15-19).

Imam Khomeini considers the interest domains that are appropriate range of sentences that the government does 
not limit the permissible area. In written and oral works of Imam synonyms have been used for the good of society, such as materials, people's interests, interests of Muslims, expediency, the interests of Islam and ...... But it was only after the problems in the society and country that Imam ordered the formation of the Expediency Council and until then, his work was not published as a book or article (Ghorbanzadeh, 2002: 17). And only the interest element has been raised parallel to and during other topics, issues.

In the first years due to the presence of the Imam, problems due to his presence and by his order were resolved or through a meeting of the heads of the three branches of government and the Prime Minister and Haj Agha Ahmad (Imam's son). But in the last years of his life, he came to the conclusion that the practices should be institutionalized (Ahwaz, 2006: 153). Imam with the expediency meeting with the Guardian Council showed that expediency, not necessarily within the framework of the principles and provisions of primary and secondary religious orders - although the term is temporary. In addition to forwarding them to reason with religious specialists and professionals in general, and it gives a special place to source Expediency (Mansurnejad, 2002: 206)

According to Imam Khomeini, like many other leaders, to keep the honor of Islam and the religion is the most important tasks. He says: "All we are obliged to protect the interests of Islam and because the most important duties is to preserve the Islamic system if there is a conflict in practice between it and the other religious orders placed sentences must be sacrificed in the province. In this regard, he stated that the government is one of the basic commandments of Islam and first of all Secondary Rules, even prayer, fasting and pilgrimage, the legal contracts dcan be revoke that are related to the public when the contract is against the interests of the country and Islam unilaterally. "(Khomeini, 1999: 171-170)

In his opinion: "In Islam, the expediency is of the issues that take precedence over everything and everyone must obey it." (Khomeini, 1999: 335)

He considers one of the basic concepts of the common good in our times, Muslim ruler and ruled supreme in this way makes associated with this issue: "If we say Infallible Imam is responsible about the divorce and the wife of a man selling his property although public interest does not require it, the supreme leader is not responsible anymore in the affairs." (Imam Khomeini, 1986: 66)

Imam applied expediency twice and both in the case of the resignation of Ayatollah Montazeri and asked the mass media: "It's easy for people to make clear that in Islam, the expediency is of the issues that take precedence over everything. And the same is subject to parliamentarians wrote: "With the congested heart, I put my life aside for expediency and Islam." (Imam Khomeini, 1999: 116) According to Imam, the issues that should be considered by the leader and ruler, is the fulfillment the nation interests. The government must act in accordance with the aspirations of the nation, and decide according to the nation.

In response to the question of how contracts remain between Iran and Germany, he believed that contracts must be in favor of the nation, and in the Iranian capital operate in Germany advised that it should be applied along with the interest of the nation. (Khomeini, 1999 259)

To control the Internal Affairs said:

"We refined the offices as good of the nation and country." (Imam Khomeini, 1999: 66)

In terms of his political and military issues, the interest of Muslims should be treated. He believed that to repel the strong enemy that invaded the domain of Islam and the only way to repel the enemy, is to put the weapon to a group of infidels, even for free, to protect the dignity of state and government. In his view, the defense of the realm of Islam in such circumstances is not something that the criteria is considered but it obeys the expedient time and circumstances of the time. (Khomeini, 1415 AH: 152)

\section{Abu Isac Shatby}

\subsection{Biographies of Abu Isac Shatby}

According to the narrative, his full name is Abu Isac Ibrahim bin Musa bin Mohammed Lakhmids Shatby and he is a member of Arabic Lakhmids tribe. He was born in Shatebeh and later lived in Granada (capital of the Kingdom Nasri - Granada). (Khalid Massoud, 2003). Granada At that time, it was not stable politically, had become a center of learning that attracted scholars in many of these countries. The great scholars of contemporary can refere to Shatby, Sharif Telmasany (d. 771), Ibn Khaldun (d. 808), Khatib Telmasany (d. 776) and Abu Abdollah Maqarri (d. 758). (Massoud, 1999: 28) He transmitted knowledge and had the entire knowledge in the wisdom school but his major interest was in Arabic and in particular the principles of jurisprudence. Shatby source of attachment to the principles of jurisprudence was due to his attention to this 
point that is the weakness of the law in dealing with the challenges of social change, more disabled failure from the perspective of jurisprudence and philosophical methodology.

Shatby despite little knowledge about the profession that are available, three careers have been guessed for him, Imam and khatib, Mufti, and a lecturer at the School of Granada (Granada). When Shatby assume his positions, he was accused of heresy.

His book titled Protest described the details of the problem, when decides to make his way back to his place of heresy by the guards who was covered noble tradition, a stranger among the majority of the community. He was hesitating between two issues: Whether he must follow the tradition and its time to pay the ritual of opposition or to follow the religion and traditions and ancients of the religious opposition. He decides to reach salvation following the tradition. Even if he die in this way. After a loss of continuity in this way, he was accused of blasphemy and heresy. He articulates charges brought against him in the same book:

1) Since reading prayers in a collective manner after the prayer was not accepted, accused him who believes not do any good to pray.

2) He was accused to Shia extremist (Refusal) and hatred of those because the name of the caliphs procedures was refused in the sermon.

3) The accused was charged with rebellion against the rulers. Because it does not bring in a sermon.

4) He was accused to confirm hardship in religion because he remained faithful to the tradition that was based assignments and issuing fatwas. And they have issued fatwas based on what was appropriate for the researcher.

5) He was accused to hate God's saints because it is opposed by some Sufis heretics and was in conflict with tradition. (Shatby, 1416 AH, Vol. 1: 20-9)

"He was died on the eighth of Sha'ban 790/2009." (Khalid Masoud, 2003: 136) "His well-known works are more written in Arabic language and literature and jurisprudence are: 1- Explain the Summa in grammar, 2- The title of the agreement in the science of derivation, 3. Book of origins of grammar, 4 Statements and Alanchadat / Construction, 5- Book of councils, 6- Approvals, 7- Book of Protest, 8-a medical treatise that is the Leiden University. 9-fatwas. "(Khalid Masoud, 2003: 146)

\subsection{Political Situation and Modern History of Shatby}

Grenada was that period to a rapidly changing society. Changes, such as changes in the new educational system, changing notions of authority among jurists, influence of Sufism, philosophy, theoretical and prompted Shatby to follow these developments with great interest. Granada had attracted many immigrants in this period. Many Muslims because of religious persecution by Christians have migrated to there. Also, many Berbers migrated there as Sufi and mercenaries students and seeking to gain a wealth of Africa. The economic and social interactions but what most of all makde Shatby mind busy, Sufi was devised various ways. In the previous stage acting books on Sufism but more important was the way in this new phase of Conduct these issues are considered prohibited without Sheikh Shatby, according to the opinion of Sheikh Superiority over all religious leaders it's almost meaning religious authority was no longer claim to deserve the Prophet. (Shatby, 1421: 208) The other concern of Shatby was the behavior and actions at that time it was common among Muslims. Using thename of the ruling Sultan and Caliph after the prayers or sermons in mosques, these actions caused the protest of Shatby, so that when he was the imam, he showed to disregard publically opposition. Which led to unpleasant consequences for him. Removal from office, including the imprisonment and trial.

The prominent and notable issues of Shatby life were fatwas that due to the economic and social conditions of his time, they were forced to issue. Issues that he knew them as prohibit in compliance with social change. More was in rituals, worship, family, and consecrated.

\subsection{Philosophy Interest to Shatby}

Shatby raised his theory of the interest by the four-volume of Approvals. Many contemporary Muslim authors remembered Shatby as a reference in legal affairs and theories. Some have been attributed his high-ranking position again (religious reformer who appears in every century). Of 1960 almost all the literature on Islamic law is referred to Approvals by Shatby. This indicates that he is of theoretical significance.

Before each word, it must be said that the law according to Shatby essentially linked with the concept of revelation. The ontological concept of the law is inconsistent with world. This discrepancy consequences are very important for the law. From the perspective of Shatby, world and law differ in the sense that are two different aspects of God. The world reflects the creative and legislative aspects of the law and the law is an expression of Divine Will and aspects of legislation. As a result, there is a necessary relationship between the 
will and creative aspects, but not in the aspects of legislation. Sharia is synonymous of revelation law. (Khalid Masud, 2003: 230) But, according to Shatby Quran by law have the same meaning. According to him, the term can also be attributed to hadith of the Prophet, the tradition, and tradition companions (Shatby, 1421, vol. 1 and 2). According to him, however, is certain Koranic precepts and traditions only in certain general provisions and in particular, the suspicion (Shatby, 1421, vol. 4: 7). Only the absolute lawgiver is God. Prophet, the mufti and religious jurists, are appointed by God. (Shatby, $1421 \mathrm{AH}: 245$ )

Shatby believed that before the revelation of the law, Human reason follow his desires and goals because of the passions and accidentally does not to explore materials. Human imagine taking steps in the right way, but chose the detours and wrong way to travel and behavior, once the concepts of freedom and gave rise to algebra. But God had Ltfsh including humans, and sent messengers with laws for human modification. Of course, he never thinks without the law there is no time to be human. And finally the law of the Prophet Muhammad leads His book, the Quran, was the criterion for the diagnosis of certainty of doubt. (Shatby, 1421 AH: Vol. 1: 20-19)

General principles of belief in God was revealed in Mecca, the Prophet and the Resurrection. And General Provisions such as prayer, alms and moral judgments about justice and righteousness was revealed. After the Prophet's migration to Medina and the spread of Islam, the general principles revealed in Mecca were completed with other provisions such as contracts and impose punishment.... (Shatby, $1421 \mathrm{AH}$, Vol. 1: 20-19) With the conflicts that took place between the Muslims, the Prophet, sometimes as Allah's Koran message, sometimes as tradition. And scholars have followed the task of applying these rules and regulations. They wanted to follow the provisions on the exercise of their behavior, and this was the start of discretion. (Shatby, $1421 \mathrm{AH}, \mathrm{Vol} .4$ : 239-233)

Shatby view, has never been revealed in Mecca basic principles that have not changed since the basic principles, and only minor cases have been abrogated. (Shatby, $1421 \mathrm{AH}$, Vol. 4: 236). So, according to him, personal legal development in a particular case is possible. And two legal institutions and judicial verdicts that he believes the provinces should assume the task. The establishment of these two institutions as well as the establishment of the State must have sufficiency. The sufficiency requirements, achieve the public interest, because the emphasis is on community life and individual life, social life. It means the motion for the benefit of others. Hence, of the law is generally accepted social and public institutions in the interests. (Shatby, 1421, vol. 4: 179-177) Shatby thought mufti as the successor of the Prophet's representative. Mufti is both the legislator and the interpreter of the law and its enforcement. "Mufti knowledge derived from or inferred to the law, or the transmission of traditions. In the first case, he plays a role as a missionary and the latter case of sentence is his responnsibility. This task makes the Mufti competent true successor of the Prophet (Caliph). "(Shatby, 1421: vol. 4: 246-244) The Shatby laws have been adopted to ensure Building servants. The law obligations, including the essential interests lead to the people basic, or public perfections. The materials or purposes are: Keep the faith, keep the soul, keep the generation, protection of property, and preservation of wisdom. These materials comply with the law in two ways: Existence and non-existence. Although the rules are maintained through legislation that such worship and privation through the elimination of waste containing fields of this material, such as decreed the killing of apostates. (Eslami, 1995: 310). He divides the purposes or materials to the essential, needed, and admired. As previously mentioned, five classes were stratified that are necessary to keep the material world and the hereafter, and the loss of them cause the loss of human happiness in this world and the Hereafter. The needed or perect interests, who completed the five best interest, arguing that, although subordinate to sacrifice the interests of expediency principle should ignore them. It means: the observance of the principle of important and less important where materials becomes the sacrifice of more important. Shatby believe that religious duties in support of the purposes of the law that finally the protection of the interests of the people have come into existence. After Shatby when he speaks to the issue of assignment of interests, purposes and materials in his view the two are synonymous with each other. His religious obligations divide to three groups: maintain the positive aspects of the devotional practices, habits, and split transactions, and assignments that are in denial mode crimes. Prayers, who aim to keep religion as belief and expression of faith and prayer, and so on. Habits goal is preserving the soul and the intellect like drink and clothing, and so on. And in the case of transactions also aim to maintain a sense of self and well-being. As for the definition of the penalties it believes that punishment to fix that prevents the realization of the associated materials such as retaliation to protect the interests of the soul. (Khalid Massoud, 2003: 254-252)

He defines the interest as, "I mean the interest in absolute terms that is associated with the survival of human life, the completion of human sustenance, and whatever obliges his mood and mental education." (Shatby, $1421 \mathrm{AH}$, vol. 2: 25). He also divided the materials into materials or the hereafter.

Worldly materials, including materials that make it from two angles, it can be seen: 1) see them as they really are. 
2) Find it on the basis of religious statements. We do not spend on view for the first expedient materials, but it is also associated with hardship and inconvenience are all sorts of vices that are not pure but sometimes mixed with comfort and pleasure. The second approach is also seen in the religious orations. That is what corruption and worldly materials determined the dominant ways a matter, topics addressed are legal. To overcome what is evil and the good, the legislator is not the goal. So the question arises how they are not the legislator's intention, but still have interest? Shatby replies that the only non-dominant habits acquired are deemed as interest, ie without the legal conditions to add interest.

In the case of materials of hereafter also believes that the materials, such as pure heavenly bliss are also mixed as the punishment of hell, which sometimes includes the theists as well. All materials and otherworldly evil is determined according to the law, because no reason has no place in the afterlife. (Khalid Masoud, 2003: 261-256). According to the above Shatby interest rules as proposed features:

1) The purpose of legislation is to bring worldly and other-worldly materials. Of course, so as it does not result in shariah system disorder.

2) The goal of legislator, is absolute materials. 3. The above two features are considered for this reason that the law applies to all assignments, religiously accountable, Drmhtva context of eternity, universality, and its popularity.

According to him, things like relativism and subjective desires and passions led to the concept of interest. From the perspective of the materials heavenly are not earthly independent of materials. And these materials as long as they have homework, known only by law. To achieve worldly materials, creating a secular reformer is inevitable. Maliki, who alleged that their faith by adhering to two principles Shatby to expand the coverage and barrier materials Zray, actually believed that the purpose of interpreting it. The theory that purpose in the second century and later by Abu Hamid al-Ghazali's works are scattered Al-Juwayni and (d $505 \mathrm{AH})$ and was coordinated by Shatby became a theory. Shatby said that the interests and Corruption valuable because it is excreted Life of this world for the hereafter life is kept alive, not because the desire to attract ordinary materials disposal of corruption is normal. Relying on the religious dimension and in the Hereafter interest, has led to the discovery of three principal since law perspective about materials and corruption are expedient to make such a general definition. Thus, to explain the criteria Field For markers of interest in civil transactions have not paid. The exception is Shatby; It can be a thorough investigation into his words this definition won: The good thing is that the good or the public interest or there are private and the human population the improvement of living conditions compatible. (Eslami, 2003: 261- 314)

\section{Comparing the Interest in the Ideas of Imam Komeini and Shatby}

Theory of interest from the perspective of these two great jurists contains key points and also reflects the growth and development in the field of Islamic jurisprudence. To match these two prominent Sunni and Shi'a jurists about interest subject, is very difficult and sensitive. For a closer look at similarities and differences between the big tow worlds in the matter of interest, we organize content on two topics:

\subsection{Fundamental Difference between the Two Approaches}

There are several differences between the two theories. Among the reasons listed on the principles of Sunni will not be accepted in theory Imam Khomeini Shi'ite doctrine in general and in particular. For example, the principles of Shiite jurisprudence such things as reclamation, istihsan, and Mursala materials, waste dam, and does not know as compared breeder causative as evidence of deduction.

But the most important difference between the two theories should be sought in two points:

1-reliance deemed to Imam Khomeini's theory, based on the theory of velayat-e faqih. In fact, interest in their views explained within the framework of the theory of velayat-e faqih theory.

2- In-law tradition Shiite imams also are used to refine them, and delimit concept of interest. While in theory of Shatby interest among the Sunnis in general and specifically, is not achievable.

\subsection{Similarities and Differences on Some Specific Examples}

\section{To compare position of interest}

To express the views of Imam Khomeini and Shatby had as issues in private, on the subject of interest as the case, given the importance of law of the most important and important and controversial conflict rules in the interest of Imam Khomeini.

\section{Conflict rules}


Objection between them as two orders and impossibility of compliance, conflict is said to have been discussed in legal theory and jurisprudence. Interference, is the opposition of the decision due to the impossibility of compliance between the two. Conflict, in terms of the criteria opposed the sentence as obedience, because it is responsible, is not able to do both at the same time. Clash of the "hard" and the term if the two sentences to each other interfere, so that action can not be both, say the two clash, and the two intruders judgment call. For example, when two people are drowning, and shall only be able to save one person, then two must be conflicting. But if the conflict against each other two or more due to be retractable so that it will not be because of the conflict of the two is called opposing. Wisdom dictates that in such a case that the conflict between the ruling and the importance of one over the other, must take precedence important to know, and otherwise had their man. As shown in the above example if one of the two lifeguard, if one universe, he preceded to save, otherwise their obligation has to save between them. (Muzaffar, AH 1408: 213). The Mohaqiq Naeini definition of the conflict is more accepted in the jurisprudence. In his view, the conflict between the two non-permanent opposed to a religious order, which is rooted in the legislation, but the sentence after the discovery by the jurists, the research topic as the actuality and the conflict have fallen (Kheradmandi, et al., 2013: 28-27).

\section{The difference between disturbance and conflict}

Conflict is the situation for two reasons relative to each other, but the conflict is two orders against the state. (Meshkini, 1969: 89)

The legislation is opposed for two reasons conflict, but conflict happens in the implementation of the law. (M, AH 1408: 214)

\section{Most important and important law}

According to new knowledge in the science of principles, for reference only know in conflict with law of the most important and important. The law, which is based on the provisions of the materials, is that if for the legislator, the criteria of one of the two orders is stronger than another sentence, the sentence has precedence over another. Such as repelling worse with bad law that prohibited acts is nothing but the importance of the survey. Ohm's law and the nature of the expediency and corruption in the provisions and assess them together. (Kheradmandi et al., 2013: 40-39)

But from the viewpoint of Imam Khomeini, interest is ffundamental for the government rulings and that the interest should be observed as the main principle widely. Shatby theory is presented in front of Sharia purposes. He confused the issue of good and evil that many Sunni scholars to suffer, very detailed manner says: The question that naturally occur in Sunni views this is the behavior that leads to good or for certainly is it based thought? And the same problem is confusing the good with evil and It will mean that business unit has the good sense and on the other hand with corruption. A group of Sunni scholars, Ezz Bin Abdul Salam or Qrafy, his student, believe that good and evil is not found soon, but in this world are always mixing the two together; Net interest because food is scarce, Drink, married, Tools, And housing hardship and suffering but not acquired (Alhassani, 2009). Shatby also objected to the fifth issue of the first kind the book aims to unearth and have had two different directions: One of the realization of the good in the world and that honor belongs is another legislator oration. For external realization, because the expedient and pure evil is not found, researchers have understood the good and evil based on the prevailing concept. "So when the dominant aspect, prudent, commonly called interest and if the evil is overcome, in practice known corruption and therefore, what are the two faces, Rajeh can be assigned to. Have preferred if deemed desirable and if the interest is said to be a corruption prevails, avoid it and is said to be a corruption; as it is said in similar cases. "(Al-Hassani, 2009)

But the second aspect of the interest accrues when the religious quest Is not devoid of evil, the good intention is the same and A small amount of evil unnoticed, because God does not care. Shatby said:

"If deemed appropriate after evaluating the corruption seems to be the prevailing custom, the purpose of the law and legal demands for education and if it is suffering or evil-looking, Legitimacy and appropriateness of such action is not included. If the corruption is the prevailing custom of interest, it is the intention of removing its religious corruption and it is forbidden to enter, and if there is interest or pleasure, prayer is not intended to prohibit such action. In short, it is expedient to consider net legislator not associated with evil, neither low nor high. "(Al-Hassani, 2009). The accuracy of Shatby, religious dimension of the Hereafter is placed on materials and materials in such a way that the problem is so great motivation oriented general and specific transactions. Mixing materials Shatby corruption issue can be resolved in perspective with regard to the intention of the legislator.

Imam Khomeini in addition to the good design as the basis and criteria for decision-making of the leadership of 
the Muslim community had outlined the interest in Political Thought of Islamic jurisprudence. Thus he believes that leadership and the political leadership of the Muslim community after the Prophet and Imams and in the absence of Imam Mahdi (pbuh) the positions and duties of the supreme leader and the one who must include issued tact provisions to govern the Islamic community and designs and implements programs that, Spiritual Islamic society lead to material progress. In contrast, Shatby, as proposed, believes that after God and the Prophet (PBUH), Mufti is the representative and successor of the Prophet. Mufti is both the legislator and the interpreter of the law and its enforcement. On the one hand, Imam could actually match the interest and sharia law enforcement and show that in Shiite political jurisprudence, the moral and material interests of people not only do not conflict with each other, but complete each other and if both together are considered in the decision taken by the leadership of society, society will be led to happiness at the same amplitude and spread it in all legal fields of prior jurisprudence. On the other hand, Shatby divided the interests into secular and worldly interests. His definition of expediency, it is survival of human life, and attributed to the completion of human sustenance, and study whatever mood and his mind.

\subsection{To Compare Role of Time and Place}

In connection with role of time and place of ijtihad, Imam says: "Time and space are two crucial element in ijtihad and which in the past has been a legal issue, the same goes for politics and social relations and the system may not find a new sentence economy, this means that accurate recognition and economic relations is the first issue that the political and social conditions with the old appearance has remained virtually unchanged, really is a new topic, and the new decree takes and the jurist must have dominance on the issues of their time. "(Khomeini, 1999: 251)

Imam whenever feel the conditions and circumstances have changed in such a way that the stated policies of the past, suppliers of materials, the new policy adopted and sometimes previous positions with the wrong:

"Every day we realized that this word that Today we were wrong ... his rule is another way we act, we confirm that this, we've made a mistake sir, we should do it that way. We're looking for the interests of Islam, not for our own professional development. "(Khomeini, 1999: 350)

Shatby also focuses on the importance of time and space materials community. He tried to jurisprudence by the inability respond to the challenges of their time (AH eighth Andalusia) in theory show that replied relying on the possibility of legal compliance can be their timing needs, as quoted, the theory that unjustified tolerance between the two positions. On the one hand, and implementation on the other hand, was biased and inappropriate sentences.

\subsection{To Compare Discretion}

About ijtihad, Imam believed that ijtihad requires a great reception in every arena of ideas and perceptions in it. As the Imam also verify it: "In the Islamic government should always be open and ijtihad nature always demands that the revolution on ijtihad of jurist comments in various fields, even opposed to each other, freely offered and the right to prevent someone can not make it. " (Khomeini, 1999: 177) at the gate of ijtihad, his thoughts are not unique to a particular understanding and reflection and wisdom are always understood in it. Imam Khomeini said renewing ijtihad is very well supplied. His many innovations in various spheres of government to put his name on the memorial. In fact, religious innovation must be developed science of jurisprudence.

But to fully understand ijtihad Shatby first knows religious purposes and in the second ijtihad, it can be inferred on the basis of this understanding. He believes that when man can see God's plan, will have a queen who introduces him as the caliph of the Prophet and can order based on what God has made known to him. His knowledge and understanding is based on sharia knowledge and objectives, but he believed that for the fatwa should also note the issues. Among these provisions is not considered that the objectives and purposes of the provisions of principle is important. Or the generalities and details should be considered simultaneously and the most important principle is to attract good and repel evil and this is an issue that is very important to note the results of their fatwas. In his view it is not addressing the issue, beneath priest and at the same time it does not mean that the jurist say something today and tomorrow is contrary to express it, but to study specific areas to measure the effectiveness of their fatwa (Eslami, 1995: 301-316).

\subsection{Differences in Methodology}

According to highlight the Shatby theory of Islamic philosophy, have so far not been any comprehensive research and theories always about it x. As Fazl-al Rahman in his book "Islamic methodology in history" makes Shatby talk about ijtihad requires the contradiction. This is the essential task of ijtihad Muslims; with the condition that is not inconsistent with the purposes of the law. According to Rahman, this condition is 
unacceptable, because God objectives cannot be achieved except through ijtihad (Masoud, 2003: 227). Some believe that Shatby accepts Ghazali's theory of interest and Ghazali has the ubiquitous influence on Shatby, and as Ghazali did not accept the mursala materials, Shatby also believes Islamic law is immutable theory. However, due to the perception and interpretations of the book Approvals by Shatby, there are different interpretations of key terms such as innovation, worship, religion, etc. While all the above terms Shatby of the good harvest depends on his theory based on Sharia purposes. Approvals by Shatby is an example of the works of jurisprudence principles that was developed in connection with a particular legal culture and the problems that the author recognized in some parts of that culture. Lack of issues such as the consensus, analogy, arguing legal and other issues are well spotted. As a result, it seems that the removal of these issues was due to the fact that their Shatby associated with a particular message for the Sufis and scholars and their criticism was not addressed.

On the other hand, incredibly detailed discussion of such subjects as sentences of five legal permitted him and his strong claims in this regard, suggests that these discussions, context will provide the necessary ground for the expression of criticism. Of course, his only critical issues related to deviations and abuses were not religious, but equally to encourage discussions were aimed at reforming and restructuring. In a religious science of peripheral and repeat seriously be avoided, clearly indicates the way Shatby arguments persuasive style of his work, something that exactly replicates its original features and peripheral. The peripheral is necessary to repeat the arguments. Certainly, the rational inductive method was perfected before Shatby but he is the only scientist of jurisprudence, we know the method used in the surface of this complexity and to achieve such strong results. It seems that the importance of inductive Shatby as it was in service of jurisprudence, it was unclear to his descendants. But the methodology of Imam Khomein is based on the methodology of Sheikh Mofid. His view on the interest, is not only the religious perspective in all areas of political, economic, social, and.... come as the supreme leader.

\section{Conclusion}

Interest includes general meanings and has plenty of examples to strict sense, especially Sunni consider sometimes very broad meanings about the interest including maintaining quintuple materials (religion, tail, property, life, and honor), and all the commandments legislator's actually one of the materials described below. Causes and gate of Sharia in the sense are defined as interest and has the general sense. But when we speak of expediency mean it is more detailed. It seems interest, principally is defined as the conflict and sense of urgency, and to solve a problem and prefer some over others sentences or parts of sentences about finding the decision to leave. Several principles should bear in mind the interests of:

- All humans are disposed of corruption to meet their needs in recruiting and materials.

In the religion of Islam in legislation, in addition to happiness in this world, happiness is discussed for hereafter, both earthly bliss and eternal happiness.

- The body responsible for determining the corruptions, the wisdom is involved in addition to the holy legislator. The reason in the field of Vacuum and religious issues and legal requirements can detect corruptions.

The importance of expediency, in the provinces and theocracy Becomes much more important, because the Islamic government fixed and variable containing the provisions that by maintaining constant their faith responsibility for resolving the crisis sees at different times. Supreme Leader as reference expediency in occultation, it works through a mechanism that is external interest and internal mechanism according to its own academic abilities. Although Imam Khomeini's theological discussions, principles, And jurisprudence on lower interest have been stopped but in the ruling Shiite Islam in the Islamic Republic, interest is used to solve many problems related to Islamic community and have insisted on it. In his view, the ruler has absolute control of the government based on the public interest. This can best interests of the people even at the cost of Governmental temporary closure of Shari'a punishment. He formed the Expediency Council tried to multiple disputes between parliament and the Guardian Council to resolve. Due to the interest component as a sub-element that could even go beyond the framework of primary and secondary emerging to solve their problems, in his theory is to be followed. Shatby from the perspective of jurisprudence for the realization of eternal materials, building materials world is inevitable.

Abu Isac Shatby, analyzing the interest as the goal of Islamic law has tried to apply the principles of jurisprudence and rigid determinism factors of theological and methodological considerations, flout. In fact, Concept of interest to Shatby, correcting the many traditional and new misunderstanding of the concept. From the perspective of his interest, the principle of complementarity that uniform law, creates stability, and religious developments that direction. 


\section{References}

Ahwazi, A. R. (2006). Imam Khomeini narrated by Ayatollah Hashemi Rafsanjani, Tehran, Institute for the Publication of Imam Khomeini's ascension.

Alamian, A. A. (2008). From Jawaheri law to Interest Jurisprudence. Android Qom Review Press.

Al-Hussani, E. (2009). meaning of interest from the perspective of Shatby. Translator: Mehdi Mehrizi, the official website and inviting religion.

AlMohaqiq bin Hassan Al Salman, Ibrahim ibn Musa al, 1421 AH, Approvals, Egypt, Ibn 'Affan, c 1.ya' Alter, $16 \mathrm{C}$.

Amini, R. (1999). ligh scripture (5th ed., vol. 21). Tehran, Ministry of Culture and Islamic Guidance.

Fathi, Y. (2008, Summer). interest and obligation relations in political thought of Imam Khomeini. Islamic Revolution Studies Journal, (13).

Ghazali, A. H. M. (1302 AH). Refined knowledge of principles (Vol. 1). Qom, Daralzakhayr.

Ghorbanzadeh Sawar, G. (2002). the foundations of public interest in the political thought of Imam Khomeini. Tehran, Institute of Imam Khomeini and the Islamic Revolution, Vice President of Research.

Hosseini, A. (2001). theory of interest from the viewpoint of Imam Khomeini, Part I, thought honest, Issue 5, winter.

Hurr Ameli, Mohammed ibn Hasan. (1414 BC). Wasael, research Rabbani, Shiraz, Qom, published by Al-Bayt.

Islami, H. (1995). Religion Objectives, Review of Purposes at the motherland theory Alshatby, review, number 5.

Khalid Masood, M. (2003). Philosophy of Islamic Law, Mohammad Reza Zafari, Fakhruddin Asghari AghMashhadi, garden of books.

Kheradmandi, S., \& Mousavi, S. M. (2013). the implementation of the provisions of interference in the legal, law enforcement Knowledge of West Azerbaijan, Issue Twenty-one.

Khomeini, R. (1997). to refine the principles (Vol. 4). Tehran, Institute for Compilation and Publication of Imam Khomeini's Works.

Khomeini, R. (1999). light scripture (5th ed., vol. 20). Tehran, Ministry of Culture and Islamic Guidance.

Khomeini, R. (2007). Taheri Khoramabadi, H., Vending, Institute for Compilation and Publication of Imam Khomeini, Qom, Vol. 2.

Mansurnejad, M. (2002). a comparative study of the interaction of people and the ruler of view of Imam Mohammad Ghazali and Imam Khomeini. Tehran, Institute of Imam Khomeini and the Islamic Revolution, EDC.

Masood, M., \& Abbas, I. (1999). literature and language, a Academy, No. 14 from 27 to 41.

Meshkini, A. (1969). the terms principle (6th ed.). publishing wisdom.

Moradi nia, M. J. (2006). house to house with Khomeini. Tehran, publishing ascension Institute.

Muzaffar, M. R. (2005). principles of jurisprudence, and Ali Mohsen Gharavian Shyrvanyqm, Dar.

\section{Copyrights}

Copyright for this article is retained by the author(s), with first publication rights granted to the journal.

This is an open-access article distributed under the terms and conditions of the Creative Commons Attribution license (http://creativecommons.org/licenses/by/4.0/). 